\title{
Survey and Thought of Financial Management and Education in High School Students in Nanjing
}

\author{
Weiyi $\mathrm{Su}^{1}$, Mengting Deng ${ }^{2}$ \\ ${ }^{1}$ Hohai University, Nanjing, China \\ ${ }^{2}$ Nanjing Normal University, Nanjing, China \\ Email: \{ce6301278, ce47554771\}@126.com \\ Received March $12^{\text {th }}$, revised April $8^{\text {th }}$, 2012; accepted April 20 ${ }^{\text {th }}, 2012$
}

\begin{abstract}
There is a need to improve the financial management ability of high school students in China. This paper carries on a questionnaire survey among some high school students in Nanjing, then analyzes and summarizes the survey data in order to know the students' consumption psychology, financial management consciousness and financial education situation. The initial findings reveal that there is limited knowledge of the concept of financial management in high school students. This is reflected in the ability of independent living of high school students being improved. So, this paper has some specific suggestions, e.g. financial institutions and social should provide a wide variety of financial products which are suitable for high school students, and set up education bank so as to keep the sustainable development of education cause. Schools may establish parents committee in order to strengthen the relations between parents and schools, complete the quality-oriented education including financial education.
\end{abstract}

Keywords: Financial Management; High School; Family Education; Questionnaire Survey; Quality-Oriented Education

\section{Introduction}

High school students are the country's future masters. In order to make them to integrate into society smoothly in the future, we should carry out finance education as early as possible. In fact, the financial education to high school students is totally stagnant for a long time, their financial knowledge is blank. According to the survey report in "The High School Students" magazine, $79 \%$ of high school students never summarize the expenses of their pocket money, 64\% high school students have no plan for their pocket money, and only $12 \%$ of high school students have short summary and budget.

Modern economy is monetary economy. Money plays a vital role in this society (Jin, 2011). Financial management is an effective way to manage private property. Everyone has personal property, which will involve financial problems. High school students will enter the society soon. Their financial management abilities will directly impact on their future living ways and life attitude. So, it is imperative to perfect financial education.

Today, the living standard is keeping growing. Parents always spoil their kids. They give children more and more pocket money and lucky money (When Spring Festival comes, in order to bless to the younger generation, the elders give them a certain amount of cash, this cash is called lucky money). However, where does this money spend on? Are these consumers spending reasonable? What kind of financial management idea should high school students have? What effect does the family financial education bring? Our study group hopes that through the questionnaire we can form a general picture of the students' financial management condition, find out the characteristics, analyze and find out the cause with the knowledge we have, and then put forward some rational suggestions (Ping \& Qing,
2011).

\section{Survey Results and Analysis}

We carried on a questionnaire survey among 200 high school students in Nanjing, returned 173 effective questionnaires, the valid return rate was $86.5 \%$. The following is our data collection and analysis:

1) How much pocket money do you have monthly in total? (Not including necessary living)

A) $0 \sim 50$

B) $50 \sim 100$

C) $100 \sim 200$

D) $200 \sim 500$

E) More than 500

$39.3 \%$ of the students chose the " $0 \sim 50$ ", $25.0 \%$ of the students chose the " $50 \sim 100$ ", $18.5 \%$ of the students chose the " $100 \sim 200$ ", $12.5 \%$ of the students chose the " $200 \sim 500$ ", $4.7 \%$ of the students chose the "more than 500 ".

Judging from the data, students' pocket money should be quite adequate if they use properly.

2) When do you use up your pocket money every month?

A) Within half month

B) Half to one month

C) More than one month

$12.3 \%$ of the students chose the "within half month", $35.9 \%$ of the students chose the "half to one month", $51.8 \%$ of the students chose the "more than one month".

It indicates more than half of the students can manage their spending and already have save and storage consciousness, but there are still $12.3 \%$ of the students used up their pocket money within half month. It is an extravagant and waste phenomenon, which is not advisable. 
3) Your main consumption projects are (according to the amount of spending percentage, can select more than one):
A) Daily necessities
B) Books and newspaper
C) Telephone charge
D) Buy costumes
E) Buy snacks
F) Making track for star
G) Buy stationery
H) Buy electronics products
I) Play games, surf the net
J) Others (e.g.)

The proportion of the options such as "daily necessities", "books and newspaper”, "buy snacks”, "buy stationery” and "telephone charge" is quite high.

It indicates that most students can divide up the money reasonably, but there are also some students spending money on some unreasonable aspects such as snacks, telephone charge, making track for star, and so on (Chou, $\mathrm{Yu}$, Chen, \& Wu, 2009).

4) Do you have your consumption plan or account book:

A) Know it

B) Basically know in mind

C) No concept

$49.5 \%$ of students chose the "know it", $32.4 \%$ chose the "no concept".

5) Do you want to make up financial management plan?

A) Yes

B) No

$59.7 \%$ of students chose the "no".

The result indicates that most of students lack certain planning in finance management. They can not make spending plan very well according to their own needs and ability.

6) Do your parents often complain of your wasting money?

A) Always

B) Occasional

C) Never

91.2\% of students chose the "occasional" or "never".

It indicates that the parents don't concern their children in finance management.

7) Do your parents use some effective way to supervise your pocket money?

A) Yes

B) No

$63.4 \%$ of the students chose the "no".

The result indicates that child's consumption is unconcerned by parents, and it causes poor financial management ability of high school students.

8) Do you learn some financial management knowledge initiatively?

A) Yes

B) No

$25 \%$ of students chose the "Yes", $75 \%$ of students chose the "No".

It indicates more than half of the students have no financial management consciousness and concepts, they think pocket money is given by their parents, they can use up all pocket money, they needn't learn financial management knowledge.

9) Do you think high school students need to learn financial management knowledge?
A) Yes
B) No

$66.7 \%$ of students chose the "Yes", $33.3 \%$ of students chose the "No".

According to this phenomenon, we can know, the students think financial management knowledge is quite important, but they are lacking initiatives to study it.

10) Do your parents tell you true information about family finances?

A) Yes

B) Vague

C) No

More than half of the students chose the "Yes", a few chose the "vague" and almost no students chose the "no" (Jin, 2011).

11) Do your parents pay attention to your financial management education?

A) Family education is quite successful

B) Noticed, had some education

C) Indirect effects in life

D) No

Most students chose the "noticed, had some education" or the "indirect effects in life", few students chose the "family education is quite successful" or "no".

12) Parents know your financial management status and ability:

A) Know it very well

B) Clearly know

C) Know

D) Don't know

E) Never concerned

Most students chose the "know", few chose the "don't know" or "never concerned".

13) Family's and social's influence to your financial management ideas is:

A) Very deep

B) General

C) Almost no

$62.2 \%$ of students chose the "general".

14) Where do you get financial management knowledge?

A) Family

B) TV, books and newspapers

C) By myself

D) Others (e.g.)

Most students chose the "by myself" and others chose the "TV, books and newspapers" or "family".

The result of above five questions indicates that most parents have consciousness to cultivate children's financial management ability, but there are few motivated actions, so that the students can not correct their wrong idea and actions Sometimes they even be mislead by the media and buy luxuries blindly, it caused the decline of their self-care abilities. Since reforming and opening up, people's living standards improved quickly, most of students don't have to worry about life, parents always meet the needs of them while there are few parents cultivating the children's financial management concept and ability, this causes the students depending on their parents and losing independent ability.

15) If you buy a new mobile phone, what will you think first?

A) Cheap and fine, suitable for myself

B) The latest high-grade mobile phone

C) Advertising recommend or lots of students are using it

D) Be different

E) The cheaper, the better 
$61.8 \%$ of students chose the "cheap and fine, suitable for myself”, it embodied realistic consumption psychology.

$12.7 \%$ of students chose the "the latest high-grade mobile phone”, we don't think this is necessary, it embodied competition psychology.

$15.5 \%$ of students chose the "advertising recommend or lots of students are using it", their consumption is a bit blind.

$5.6 \%$ of students chose the "be different", they also have a certain seeking difference psychology, it not advisable.

$4.4 \%$ of students chose "The cheaper, the better", these students ignore their normal life demand.

16) In holiday, or on classmates' birthday, you send what types of presents:

A) Practical, suitable for them

B) Very expensive

C) Send the same as others

D) Don't send

$11.8 \%$ of students chose the "don't send”, it shows a small part of classmates have frugal consciousness, but this maybe excessive.

$14.9 \%$ of students chose the "send the same as others".

$18.2 \%$ of students chose the "very expensive", it shows that students have competition psychology, consumption has a certain blindness.

$55.1 \%$ of students chose the "practical, suitable for them", it shows that realistic psychology is dominant.

17) Will you discard the goods you buy soon?

A) Most

B) Few

C) No

Choosing "most”, "few" and "no" proportion is about 3:8:1.

18) Do you sometimes have impulse on shopping?

A) Yes

B) No

81.4\% of students chose the "Yes". Students have no independent source of income. Their money is mainly given by parents. The economic source of high school students is not stable, but it is enough. Because of these two characteristics, adding to some parents' no interference, teenagers are in consumption free. They follow the inclinations of themselves. This also greatly affects high school students' consumption behavior.

19) How do you use your lucky money?

A) Be in the bank

B) To pay tuition fee

C) Buy financial products

D) Spend it at random

E) Others (e.g.)

Most students chose the "be in the bank" or "to pay tuition fee", others chose the "spend it at random".

It shows that most students is awake, they spend their money correctly. But there are still a lot of students choosing "spend it at random”, their financial management consciousness is very weak.

20) What do you think about the teenagers' inflated desire of money?
A) Social problems
B) Family's responsibility
C) Should take action as soon as possible
D) This will never happen
73.9\% of the students chose the "social problems" and "fam- ily responsibility”.

Judging from the survey, most high school students don't have clear financial management concept and method. Some students even have the negative consumption psychology such as following the tide, seeking difference and etc. In addition to the reason of their own, the family and social factors are more important. Most students said they had no formal financial education. What they were taught is that learning their subjects well is the most important thing, we can even imagine, their parents would tell them: "Honey, we earn money, you just need to concentrate on studying".

However, the result of such family education is wasting. Teenagers have no good habit, sometimes they are even beyond saving, this has bad effect on building the right financial management concept, and this impact will emerge in the future. Being unable to manage money will affect the quality of life, if we learn more about the financial management, we can let limited money deserve more.

\section{The Thought of Financial Management Education}

Firstly, educators should pay high attention in it in order to strengthen the students' financial management consciousness and improve students' financial management ability. Educators must change their ideas practically, go out of the vicious circle of exam-oriented education, and put financial management education into the track of moral education. Secondly, grasping tireless in action, financial management education is a systematic project, the school should carry out financial management education activities. For example, invite experts to give the students some speeches about financial education, often propagandize financial management knowledge to students with newspaper and radio station and etc, hold the parents' meeting and stress the importance of financial education. Thirdly, strengthen the theory research. The financial management education of high school students is only at the beginning stage in our country, it needs educators to study and practice hard, pay attention to theory research, enrich, deepen and expand the content of financial management education, summarized the effective method and standard, study the inner connection between financial management education and other quality education, discuss how to carry out financial management education in family, let high school students conduct financial management earlier.

Parents are children's first teachers, they play the very important roles in the education of students. First, all parents should change concept, neither be too strict with their children, give them enough space to improve financial management ability, nor be too wide, must exercise their independent abilities and give them correct guide in time. Second, parents must pay attention to their action, let children have right consumption conception.

Schools may establish parents committee in order to strengthen the relations between parents and schools. Teachers guide the education methods for parents and parents can know their kids' performance in school. They can give schools some specific requirements and suggestions, complete the quality-oriented education including financial management in high school students.

Students are the masters of themselves. They should train and improve their financial management ability. Students shouldn't depend too much on family. They should have the 
independent consciousness. Financial management is not only to dominate pocket money at present, but also to set up a good foundation for the future.

We hope that financial institutions and social should provide a wide variety of financial products which are suitable for high school students. Then students could study knowledge and conduct financial management at the same time. Education department may establish education bank, it could not only be convenient for teachers' and students' financial management, but also invest some schools which lack education funds (Chapman \& Greenaway, 2006; The Task Force, 2000).

\section{Acknowledgements}

We would like to thank Yaohua Liu, Mengyuan Liu, Na Liu, Xiaorui Tan and Xiaolin Fang for their help, thank our high school teacher HongLiang $\mathrm{Li}$ for his meticulous guidance, thank our leaders and professors in Hohai University and Nanjing Normal University, they give us enough encourage and support, thank the CE editors and reviewer, the feedback is extremely valuable for us.

\section{REFERENCES}

Bryceson, D., \& Vuorela, U. (2002). Transnational families in the twenty-first century. In D. Bryceson, \& U. Vuorela, (Eds.), The transnational family: New European frontiers and global networks. Oxford: Berg.
Chamez, K. (2003). Grounded theory. In J. A. Smith (Ed.), Qualitative psychology: A practical guide to research methods (pp. 81-110).

Chapman, B., \& Greenaway, D. (2006). Learning to live with loans? International policy transfer and the funding of higher education. The World Economy, 29, 1057-1075. doi:10.1111/j.1467-9701.2006.00822.x

Chou, C., Yu, S., Chen, C., \& Wu, H. (2009). Tool, toy, telephone, territory or treasure of information: Elementary school students' atti-tudes toward the internet. Computers \& Education, 53, 308-316. doi:10.1016/j.compedu.2009.02.003

Dei, G. J. S. (2011b). Indigenous philosophies and critical education. New York, NY: Peter Lang Publishing.

Jin, L. (2011). An introduction of a financial model for the Australian high education. Creative Education, 2, 466-469. doi:10.4236/ce.2011.25068

Krueger, R. A. (1994). Focus groups: A practical guide for applied research (2nd ed.). Thousand Oaks, CA: Sage Publications.

Mayring, P. (2000). Qualitative content analysis. Forum: Qualitative Social Research, 1. URL (last checked September 2011) http://www.qualitative-research.net/fqs-texte/2-00/02-00mayring-e.htm

Ping, W., \& Qing, D. (2011). A survey of support and coping style in middle school female teachers in china. Creative Education, 2, 220-225. doi:10.4236/ce.2011.23030

Sukari, L. S. (2006). Support systems that facilitate high school teacher's PADs evaluation ratings. Ph.D. Thesis, Houston, TX: Texas Southern University.

The Task Force (2000). Higher education in developing countries: Peril and promise. Washington, DC: The World Bank.

Wang, X. (1999). Life event scale. Psychological hygiene assessment scale manual (updated version). Beijing: Chinese Psychological Hygiene Journal Publishing House. 